\title{
PENGARUH PENGALAMAN PRAKTIK KERJA INDUSTRI, INFORMASI DUNIA KERJA, DAN MOTIVASI MEMASUKI DUNIA KERJA TERHADAP KESIAPAN KERJA SISWA KELAS XII AKUNTANSI SMK N 1 PENGASIH TAHUN AJARAN 2018/2019
}

\author{
THE EFFECT OF INDUSTRIAL WORK PRACTICE'S EXPERIENCE, \\ INFORMATION THE WORLD OF WORK, AND MOTIVATION ENTERING THE \\ WORLD OF WORK TOWARD WORK READINESS OF STUDENT OF CLASS XII \\ ACCOUNTING SMK N 1 PENGASIH ACADEMIC YEAR 2018/2019
}

\author{
Oleh: \\ Lifah Lutfiani \\ Prodi Pendidikan Akuntansi Universitas Negeri Yogyakarta \\ lifah69@gmail.com \\ Moh. Djazari \\ Staf Pengajar Jurusan Pendidikan Akuntansi Universitas Negeri Yogyakarta
}

\begin{abstract}
Abstrak
Penelitian ini bertujuan untuk mengetahui: 1) Pengaruh Pengalaman Praktik Kerja Industri terhadap Kesiapan Kerja Siswa Kelas XII Akuntansi SMK N 1 Pengasih Tahun Ajaran 2018/2019. 2) Pengaruh Informasi Dunia Kerja terhadap Kesiapan Kerja Siswa Kelas XII Akuntansi SMK N 1 Pengasih Tahun Ajaran 2018/2019. 3) Pengaruh Motivasi Memasuki Dunia Kerja terhadap Kesiapan Kerja Siswa Kelas XII Akuntansi SMK N 1 Pengasih Tahun Ajaran 2018/2019. 4) Pengaruh Pengalaman Praktik Kerja Industri, Informasi Dunia Kerja, dan Motivasi Memasuki Dunia Kerja secara bersama-sama terhadap Kesiapan Kerja Siswa Kelas XII Akuntansi SMK N 1 Pengasih Tahun Ajaran 2018/2019. Penelitian ini merupakan penelitian ex post facto. Populasi dalam penelitian ini adalah 64 Siswa Kelas XII Akuntansi SMK N 1 Pengasih Tahun Ajaran 2018/2019. Data dikumpulkan dengan menggunakan angket. Uji prasyarat analisis meliputi uji linearitas dan uji multikolinearitas. Teknik analisis data yang digunakan adalah analisis regresi sederhana dan analisis regresi ganda. Hasil penelitian ini menunjukkan bahwa: 1) Terdapat pengaruh positif Pengalaman Praktik Kerja Industri terhadap Kesiapan Kerja Siswa Kelas XII Akuntansi SMK N 1 Pengasih Tahun Ajaran 2018/2019, ditunjukkan dengan $r_{x 1 y}=0,801, r^{2} x 1 y=0,642, Y=0,582 X_{1}+11,679, t_{\text {hitung }}>t_{\text {tabel }}$ $(10,550>1,670) .2)$ Terdapat pengaruh positif Informasi Dunia Kerja terhadap Kesiapan Kerja Siswa Kelas XII Akuntansi SMK N 1 Pengasih Tahun Ajaran 2018/2019, dibuktikan dengan $\mathrm{r}_{\mathrm{x} 2 \mathrm{y}}=0,661$, $\left.\mathrm{r}^{2}{ }_{\mathrm{x} 2 \mathrm{y}}=0,437, \mathrm{Y}=0,785 \mathrm{X}_{2}+24,247, \mathrm{t}_{\text {hitung }}>\mathrm{t}_{\text {tabel }}(6,940>1,670) .3\right)$ Terdapat pengaruh positif Motivasi Memasuki Dunia Kerja terhadap Kesiapan Kerja Siswa Kelas XII Akuntansi SMK N 1 Pengasih Tahun Ajaran 2018/2019, ditunjukkan oleh $\mathrm{r}_{\mathrm{x} 3 \mathrm{y}}=0,522, \mathrm{r}_{\mathrm{x} 3 \mathrm{y}}^{2}=0,272, \mathrm{Y}=0,582 \mathrm{X}_{3}+$ $\left.27,482, t_{\text {hitung }}>t_{\text {tabel }}(4,819>1,670) .4\right)$ Terdapat pengaruh positif Pengalaman Praktik Kerja Industri, Informasi Dunia Kerja, dan Motivasi Memasuki Dunia Kerja secara bersama-sama terhadap Kesiapan Kerja Siswa Kelas XII Akuntansi SMK N 1 Pengasih Tahun Ajaran 2018/2019, dibuktikan dengan $R_{y(1,2,3)}=0,849, R_{y(1,2,3)}^{2}=0,722, Y=0,428 X_{1}+0,346 X_{2}+0,122 X_{3}+2,984, F_{\text {hitung }}>F_{\text {tabel }}(51,831>$ $2,76)$.
\end{abstract}

Kata kunci: Kesiapan Kerja, Pengalaman Praktik Kerja Industri, Informasi Dunia Kerja, Motivasi Memasuki Dunia Kerja

\section{Abstract}


This study aims to determine: 1) The effect of Industrial Work Practice's Experience toward Work Readiness of student of class XII Accounting SMK N 1 Pengasih academic year 2018/2019. 2) The effect of Information the World of Work toward Work Readiness of student of class XII Accounting SMK N 1 Pengasih academic year 2018/2019. 3) The effect of Motivation Entering the World of Work toward Work Readiness of student of class XII Accounting SMK N 1 Pengasih academic year 2018/2019. 4) The effect of Industrial Work Practice's Experience, Information the World of Work, and Motivation Entering the World of Work simultaneously toward Work Readiness of student of class XII Accounting SMK N 1 Pengasih academic year 2018/2019. The type of this research was ex post facto. The population in this research were 64 students of class XII Accounting SMK $N 1$ Pengasih academic year 2018/2019. The data were collected by using questionnaire. Test prerequisites included analysis of the linearity test and multicollinearity. Data analysis technique used a simple regression analysis and multiple regression analysis. The results of this research show that: 1) There is a positive influence of Industrial Work Practice's Experience toward Work Readiness of student of class XII Accounting SMK N 1 Pengasih academic year 2018/2019, represented by $\left.r_{x l y}=0.801, r_{x y y}^{2}=0.642, Y=0,582 X_{1}+11,679, t_{\text {count }}>t_{\text {table }}(10,550>1,670) .2\right)$ There is a positive influence on Information the World of Work toward Work Readiness of student of class XII Accounting SMK N 1 Pengasih academic year 2018/2019, evidenced by $r_{x 2 y}=0.661, r_{x 2 y}^{2}=$ 0.437, $Y=0,785 X_{2}+24,247, t_{\text {count }}>t_{\text {table }}(6,940>1,670)$. 3) There is a positive influence of Motivation Entering the World of Work toward Work Readiness of student of class XII Accounting SMK N 1 Pengasih academic year 2018/2019, indicated by $r_{x 3 y}=0.522, r_{x 3 y}^{2}=0.272, Y=0,582 X_{3}+$ $27,482, t_{\text {count }}>t_{\text {table }}(4,819>1,670)$. 4) There is a positive influence of Industrial Work Practice's Experience, Information the World of Work, and Motivation Entering the World of Work simultaneously toward Work Readiness of student of class XII Accounting SMK N 1 Pengasih academic year 2018/2019, evidenced by $R_{y(1,2,3)}=0.849, R_{y(1,2,3)}^{2}=0.722, Y=0,428 X_{1}+0,346 X_{2}+$ $0,122 X_{3}+2,984, F_{\text {count }}>F_{\text {table }}(51,831>2,76)$.

Keywords: Work Readiness, Industrial Work Practice's Experience, Information the World of Work, Motivation Entering the World of Work

\section{PENDAHULUAN}

Era sekarang ini menuntut negara-negara untuk meningkatkan seluruh sektor negara dan menyesuaikan diri dengan negara yang lain, baik dalam bidang politik, ekonomi, sosial, pendidikan, maupun ilmu pengetahuan dan teknologi. Persaingan global yang terjadi di seluruh penjuru dunia, termasuk Indonesia, akhir-akhir ini menjadi perhatian dan perbincangan publik. Karena Indonesia merupakan negara berkembang, maka peningkatan seluruh sektor negara sangatlah penting. Untuk mewujudkan hal tersebut, salah satu cara yang dapat dilakukan adalah dengan meningkatkan kualitas sumber daya manusia. Hal itu dikarenakan sumber daya manusia memiliki peran yang sangat penting di seluruh bidang dalam suatu negara. Kurang berhasilnya negara dalam meningkatkan kualitas sumber daya manusia dapat menyebabkan tertinggalnya negara tersebut dari negara yang lainnya. Indonesia dengan pertambahan penduduk yang cukup pesat, keberagaman kemampuan ekonomi, dan banyaknya penduduk yang tidak melanjutkan sekolah mengakibatkan kualitas sumber daya manusia menjadi rendah. Hal tersebut dikarenakan banyaknya penduduk yang tidak memiliki keterampilan kerja yang memadai.

Salah satu cara untuk meningkatkan kualitas sumber daya manusia adalah dengan adanya pendidikan, melalui pendidikan maka sumber daya manusia akan memiliki kompetensi dan keterampilan sesuai dengan bidang keahliannya. Dengan pendidikan, negara akan terus berkembang dan siap untuk menghadapi persaingan global. Untuk mewujudkan negara yang siap 
menghadapi persaingan global, salah satu caranya adalah dengan menciptakan pendidikan kejuruan yang mengarah pada kompetensi khusus dan sesuai dengan kebutuhan dunia kerja. Clarke \& Winch dalam buku Sofyan (2015: 5) mendefinisikan pendidikan kejuruan sebagai pendidikan yang menyiapkan generasi muda untuk memasuki lapangan kerja, juga merupakan proses yang pembelajarannya berkaitan dengan masalah teknik dan praktik. Pasal 1 Peraturan Pemerintah Republik Indonesia No. 29 Tahun 1990 tentang Pendidikan Menengah menyebutkan bahwa "Pendidikan menengah kejuruan adalah pendidikan pada jenjang pendidikan menengah yang mengutamakan pengembangan kemampuan siswa untuk melaksanakan jenis pekerjaan tertentu". Kemudian pada pasal 3 disebutkan bahwa "Pendidikan menengah kejuruan mengutamakan penyiapan siswa untuk memasuki lapangan kerja serta mengembangkan sikap profesional". Bentuk dari pendidikan menengah kejuruan ini adalah Sekolah Menengah Kejuruan (SMK). Berdasarkan tujuan dari pendidikan kejuruan tersebut, yang salah satunya adalah untuk menyiapkan siswa dalam memasuki lapangan kerja, maka Kesiapan Kerja sangat penting dan harus diperhatikan.

Menurut Mason, Williams, \& Cranmer (2006: 2), Kesiapan Kerja adalah kepemilikan keterampilan, pengetahuan, sikap, dan pemahaman komersial yang akan memungkinkan lulusan baru untuk berkontribusi secara produktif untuk mencapai tujuan organisasi segera setelah mulai bekerja. Karena Kesiapan Kerja ini sangatlah penting bagi siswa SMK, maka lembaga pendidikan perlu menjalin kerja sama dengan dunia usaha atau dunia industri. Dengan adanya hal tersebut, maka siswa tidak hanya dibekali dengan teoriteori saat di kelas saja, namun ia juga dapat melihat dan mengalami secara langsung bagaimana keadaan di dunia usaha atau dunia industri. Siswa juga dapat menerapkan teori yang sudah dipelajari di kelas ke dalam praktiknya di lapangan. Harapannya, jika siswa sudah dibekali pengalaman langsung, maka ketika sudah lulus nanti siswa sudah siap untuk terjun ke dunia kerja.

Terdapat beberapa faktor yang dapat mempengaruhi Kesiapan Kerja. Kardimin (2004: 2-9) menjelaskan bahwa ada 2 faktor yang mempengaruhi Kesiapan Kerja, yaitu faktor-faktor yang berasal dari dalam diri siswa (faktor internal) dan faktor-faktor yang berasal dari luar diri siswa (faktor eksternal). Faktor internal meliputi kematangan fisik dan mental, tekanan, minat, bakat, kemandirian, penguasaan ilmu pengetahuan, dan motivasi. Faktor eksternal meliputi peran masyarakat, keluarga, informasi dunia kerja, dan pengalaman kerja.

Salah satu faktor eksternal yang mempengaruhi Kesiapan Kerja adalah Pengalaman Praktik Kerja Industri. Menurut Hamalik (2007: 91), "Praktik Kerja Industri adalah suatu program latihan yang diselenggarakan di lapangan atau di luar kelas, dalam rangkaian kegiatan pembelajaran sebagai bagian integral program pelatihan". Jadi, Pengalaman Praktik Kerja Industri merupakan pengalaman atau kegiatan yang pernah dialami oleh siswa berkaitan dengan pelatihan yang dilaksanakan di lapangan guna menerapkan apa yang telah dipelajarinya di dalam kelas. Jika siswa telah memiliki Pengalaman Praktik Kerja Industri, berarti ia sudah mengetahui bagaimana keadaan dunia kerja yang sebenarnya, sehingga nanti ketika ia sudah lulus SMK akan siap terjun ke dunia kerja. Namun, jika Pengalaman Praktik Kerja Industrinya kurang, atau tidak sesuai dengan bidang yang sedang ditempuhnya, maka Kesiapan Kerja dalam bidangnya akan kurang. Jadi, Pengalaman Praktik Kerja Industri memiliki peran dalam mempengaruhi Kesiapan Kerja.

Faktor eksternal lainnya adalah Informasi Dunia Kerja. Informasi Dunia 
Kerja adalah keterangan yang meliputi seluruh informasi mengenai lowongan pekerjaan dan persyaratannya, yang dapat diperoleh dari berbagai sumber. Informasi Dunia Kerja ini sangat penting manfaatnya terutama bagi lulusan SMK yang ingin segera bekerja. Dengan adanya Informasi Dunia Kerja, maka siswa dapat memilih pekerjaan yang akan dijalaninya, tentunya yang sesuai dengan bidang keahliannya. Informasi Dunia Kerja juga dapat meningkatkan Kesiapan Kerja, karena dapat memberikan gambaran mengenai bagaimana pekerjaan yang sedang ditawarkan oleh lembaga atau perusahaan tertentu dan apa yang harus dikerjakan. Jika siswa sudah mengetahui pekerjaan tersebut, maka ia akan memiliki kesiapan untuk bekerja. Namun, jika siswa tidak mendapatkan Informasi Dunia Kerja, maka ia tidak memiliki gambaran untuk bekerja di mana, dan pekerjaan seperti apa yang akan ia pilih, sehingga ia merasa belum siap untuk terjun ke dunia kerja.

Faktor lain yang mempengaruhi Kesiapan Kerja yaitu dari faktor internal, dalam hal ini adalah Motivasi Memasuki Dunia Kerja. Motivasi Memasuki Dunia Kerja adalah suatu dorongan yang dimiliki oleh siswa dan timbul karena adanya tujuan untuk memasuki dunia kerja. Jika siswa memiliki kemauan dan kemampuan untuk segera bekerja, maka dari dalam diri siswa itu sendiri sudah timbul adanya motivasi untuk memasuki dunia kerja. Motivasi Memasuki Dunia Kerja timbul karena adanya hasrat dan keinginan untuk berhasil, adanya dorongan dan kebutuhan, adanya harapan dan cita-cita masa depan, adanya penghargaan, adanya kegiatan yang menarik, dan adanya lingkungan yang baik. Jika Motivasi Memasuki Dunia Kerja tinggi, maka siswa akan membekali dirinya dengan berbagai kompetensi dan keterampilan yang akan digunakan saat bekerja nanti, sehingga siswa siap untuk terjun ke dunia kerja.

Berdasarkan data penelusuran tamatan yang diperoleh peneliti di SMK $\mathrm{N} 1$
Pengasih pada tanggal 26 Juni 2018 diketahui bahwa siswa lulusan 2016/2017 dari program keahlian Akuntansi yang bekerja sebanyak 37,5\%, melanjutkan ke perguruan tinggi sebanyak $51,56 \%$, dan sebanyak $10,94 \%$ masih belum diketahui atau belum ada keterangan. Selain itu, dari data penelusuran tamatan yang diperoleh peneliti pada tanggal 14 Desember 2018 diketahui bahwa siswa lulusan 2017/2018 dari program keahlian Akuntansi yang bekerja sebanyak 48,44\%, melanjutkan ke perguruan tinggi sebanyak $20,31 \%$, yang masih belum bekerja sebanyak $26,56 \%$, dan sebanyak $4,69 \%$ belum diketahui atau belum ada keterangan. Dari data yang diperoleh tersebut, terdapat beberapa siswa yang bekerja tidak sesuai dengan bidang keahliannya, misalnya bekerja di toko sebagai pramuniaga. Hal tersebut diperkuat dengan wawancara yang dilakukan peneliti dengan salah satu guru Bimbingan Konseling (BK) yang mengatakan bahwa Kesiapan Kerja untuk memasuki dunia kerja masih belum optimal, karena terdapat beberapa kendala yang dihadapi. Kendala tersebut diantaranya adalah izin orang tua yang sulit didapatkan jika siswa akan bekerja di luar daerahnya sendiri, kemudian siswa ingin bekerja dengan gaji yang besar meskipun faktanya pekerjaan dengan gaji yang besar harus diiringi dengan kompetensi yang mumpuni pula, daya juang siswa juga masih rendah karena pekerjaan yang biasa diinginkan adalah pekerjaan yang mudah namun dengan penghasilan yang besar, dan yang terakhir adalah minder. Beberapa kendala tersebut sangat mempengaruhi Kesiapan Kerja. Selain itu, berdasarkan hasil observasi peneliti di kelas XII Akuntansi Tahun Ajaran 2018/2019, terdapat $6,5 \%$ dari 46 siswa yang masih belum memiliki gambaran tentang dunia kerja dan 45,7\% memilih untuk tidak langsung bekerja saat sudah lulus nanti. Hal tersebut menunjukkan bahwa Kesiapan Kerja masih belum maksimal. 
Selain itu, berdasarkan wawancara peneliti dengan salah satu siswa kelas XII Akuntansi 1 pada tanggal 28 Juni 2018, bahwa praktik kerja industri di SMK N 1 Pengasih dilaksanakan 3,5 bulan. Namun, fakta menunjukkan bahwa meskipun praktik kerja industri telah dilaksanakan selama 3,5 bulan, masih terdapat beberapa siswa yang belum mendapatkan pengalaman yang cukup. Hal tersebut ditunjukkan dengan adanya $15,2 \%$ dari 46 siswa yang masih belum yakin untuk segera bekerja setelah lulus nanti, meskipun telah melaksanakan praktik kerja industri. Selain itu, terdapat $13 \%$ siswa yang tidak ditempatkan di lembaga yang sesuai dengan bidang keahliannya dan $21,7 \%$ siswa yang tidak diberikan tugas yang sesuai dengan bidang keahliannya saat praktik kerja industri berlangsung. Dengan begitu, praktik kerja industri memberikan kontribusi dalam mempengaruhi Kesiapan Kerja.

Sesuai dengan hasil observasi peneliti di kelas XII Akuntansi SMK N 1 Pengasih pada tanggal 28 Juni 2018, seluruh siswa mengatakan bahwa informasi pekerjaan sangat penting setelah lulus nanti. Selain itu, 50\% dari 46 siswa juga mengatakan bahwa BK sudah memberikan informasi yang memadai mengenai dunia kerja dan lowongan pekerjaan, berarti $50 \%$ siswa masih belum merasa mendapatkan Informasi Dunia Kerja yang memadai dari BK. Hal tersebut didukung oleh hasil wawancara peneliti dengan guru BK pada tanggal 26 Juni 2018, bahwa guru BK telah menyampaikan seluruh informasi dari sekolah dan yang berkaitan dengan dunia kerja melalui grup dari sebuah aplikasi pesan singkat. Siswa juga mengatakan bahwa informasi pekerjaan biasa mereka dapatkan dari media sosial, media massa, sekolah (BK/BKK), keluarga, saudara, tetangga, teman, dinas tenaga kerja, tempat praktik kerja industri, guru pembimbing, dan lingkungan sekitar. Dari beberapa fakta tersebut, menunjukkan bahwa Informasi
Dunia Kerja memiliki peran dalam mempengaruhi Kesiapan Kerja.

Berdasarkan hasil observasi peneliti di kelas XII Akuntansi SMK N 1 Pengasih pada tanggal 28 Juni 2018, seperti yang telah dijelaskan sebelumnya bahwa terdapat $54,3 \%$ dari 46 siswa yang memilih langsung bekerja saat lulus nanti, berarti sisanya tidak akan langsung bekerja, misalnya melanjutkan ke perguruan tinggi atau istirahat sementara dari aktivitas pendidikannya. Kemudian, terdapat $76,1 \%$ siswa mengatakan bahwa pengetahuan yang selama ini dipelajari di sekolah dapat diterapkan di dunia kerja, sedangkan 23,9\% siswa mengatakan tidak. Hal-hal tersebut menunjukkan bahwa Motivasi Memasuki Dunia Kerja turut memberikan sumbangan pengaruh terhadap Kesiapan Kerja.

Berdasarkan permasalahan di atas, dilakukan penelitian terhadap masalah tersebut ke dalam skripsi dengan judul "Pengaruh Pengalaman Praktik Kerja Industri, Informasi Dunia Kerja, dan Motivasi Memasuki Dunia Kerja terhadap Kesiapan Kerja Siswa Kelas XII Akuntansi SMK N 1 Pengasih Tahun Ajaran 2018/2019", dengan harapan dapat menambah ilmu pengetahuan dan dapat meningkatkan kualitas pendidikan berkaitan dengan adanya pengaruh Pengalaman Praktik Kerja Industri, Informasi Dunia Kerja, dan Motivasi Memasuki Dunia Kerja terhadap Kesiapan Kerja siswa.

\section{METODE PENELITIAN \\ Desain Penelitian}

Penelitian ini merupakan penelitian yang menggunakan pendekatan kuantitatif yang memperoleh data dari populasi penelitian kemudian dianalisis sesuai dengan metode statistik yang digunakan. Penelitian ini merupakan penelitian ex post facto, yaitu penelitian tentang variabel yang kejadiannya sudah terjadi sebelum penelitian dilaksanakan (Arikunto, 2013: 17). Penelitian ini bertujuan untuk mengetahui pengaruh variabel bebas yaitu Pengalaman 
Praktik Kerja Industri, Informasi Dunia Kerja, dan Motivasi Memasuki Dunia Kerja terhadap variabel terikat yaitu Kesiapan Kerja.

\section{Tempat dan Waktu Penelitian}

Penelitian ini dilaksanakan di SMK N 1 Pengasih yang beralamat di Jl. Kawijo No. 11, Pengasih, Kulon Progo, Yogyakarta 55652. Tepatnya di kelas XII Akuntansi 1 dan XII Akuntansi 2 Tahun Ajaran 2018/2019. Penelitian ini dilaksanakan pada bulan Januari - Februari 2019, terdiri dari tahap persiapan, pelaksanaan, dan pelaporan.

\section{Populasi Penelitian}

Menurut Sugiyono (2015: 61), "Populasi adalah wilayah generalisasi yang terdiri atas obyek/subyek yang mempunyai kualitas dan karakteristik tertentu yang diterapkan oleh peneliti untuk dipelajari dan kemudian ditarik kesimpulannya". Populasi dalam penelitian ini adalah seluruh Siswa Kelas XII Akuntansi SMK N 1 Pengasih Tahun Ajaran 2018/2019 yang terdiri dari 2 kelas berjumlah 64 siswa.

\section{Tabel 1. Jumlah Populasi Penelitian}

\begin{tabular}{|c|c|c|}
\hline No. & Kelas & Jumlah \\
\hline 1. & XII Akuntansi 1 & 32 \\
\hline 2. & XII Akuntansi 2 & 32 \\
\hline \multicolumn{2}{|c|}{ Jumlah } & 64 \\
\hline
\end{tabular}

\section{Teknik Pengumpulan Data}

Teknik pengumpulan data yang digunakan dalam penelitian ini adalah kuesioner (angket). Menurut Sugiyono (2015: 142), "Kuesioner merupakan teknik pengumpulan data yang dilakukan dengan cara memberi seperangkat pertanyaan atau pernyataan tertulis kepada responden untuk dijawabnya". Kuesioner dapat berupa pertanyaan atau pernyataan tertutup atau terbuka, yang diberikan kepada responden secara langsung atau dikirim melalui pos atau internet. Penelitian ini menggunakan kuesioner dengan pernyataan tertutup, dan diberikan kepada responden secara langsung. Kuesioner tersebut digunakan untuk mengukur variabel terikat berupa Kesiapan Kerja, dan variabel bebas berupa Pengalaman Praktik Kerja Industri, Informasi Dunia Kerja, dan Motivasi Memasuki Dunia Kerja.

\section{Instrumen Penelitian}

"Instrumen penelitian adalah suatu alat yang digunakan untuk mengukur fenomena alam maupun sosial yang telah diamati" (Sugiyono, 2015: 102). Instrumen yang digunakan dalam penelitian ini adalah kuesioner (angket). Penelitian ini menggunakan kuesioner tertutup. Menurut Arikunto (2013: 195), kuesioner tertutup sudah menyediakan jawabannya sehingga responden tinggal memilih. Penyusunan kuesioner dalam penelitian ini merupakan penjabaran variabel terikat dan variabel bebas ke dalam indikator-indikator yang akan diukur. Dari indikator tersebut dikembangkan lagi menjadi butir-butir pernyataan. Skor instrumen yang digunakan adalah skala Likert yang dimodifikasi, yaitu dengan 4 alternatif jawaban yang diberikan skor 1 sampai 4 pada setiap pernyataan. Alternatif jawaban yang digunakan yaitu untuk menanyakan persetujuan berupa Sangat Setuju (SS), Setuju (S), Tidak Setuju (TS), dan Sangat Tidak Setuju (STS). Skor untuk setiap pernyataan positif (+) dan pernyataan negatif (-) sebagai berikut.

Tabel 2. Skor Alternatif Jawaban dengan Skala Likert yang dimodifikasi

\begin{tabular}{|c|c|c|}
\hline \multirow{2}{*}{ Alternatif Jawaban } & \multicolumn{2}{|c|}{$\begin{array}{c}\text { Skor untuk } \\
\text { Pernyataan }\end{array}$} \\
\cline { 2 - 3 } & Positif & Negatif \\
\hline Sangat Setuju (SS) & 4 & 1 \\
\hline Setuju (S) & 3 & 2 \\
\hline Tidak Setuju (TS) & 2 & 3 \\
\hline $\begin{array}{c}\text { Sangat Tidak Setuju } \\
\text { (STS) }\end{array}$ & 1 & 4 \\
\hline
\end{tabular}


Uji Coba Instrumen

Menurut Arikunto (2013: 211), instrumen yang baik adalah instrumen yang harus memenuhi dua persyaratan penting, yaitu valid dan reliabel. Sebelum instrumen digunakan dalam penelitian, harus dilakukan uji coba instrumen terlebih dahulu. Hal ini bertujuan untuk memperoleh informasi mengenai terpenuhi atau tidaknya persyaratan di atas. Uji coba instrumen dalam penelitian ini dilaksanakan di SMK N 1 Bantul pada kelas XII Akuntansi yang dianggap memiliki karakteristik yang sama dengan SMK N 1 Pengasih kelas XII Akuntansi. Uji coba tersebut dilaksanakan pada 15 Siswa Kelas XII AK3 dan 15 Siswa Kelas XII AK4 SMK N 1 Bantul Tahun Ajaran 2018/2019. Uji coba instrumen ini dilakukan dengan dua pengujian berupa uji validitas dan uji reliabilitas. Uji validitas digunakan untuk mengetahui valid atau tidaknya suatu instrumen, dengan menggunakan teknik korelasi product moment dari Karl Pearson. Uji reliabilitas pada penelitian ini menggunakan rumus Alpha Cronbach.

\section{Teknik Analisis Data}

a. Uji Prasyarat Analisis

Uji prasyarat analisis yang dilakukan sebelum melakukan pengujian hipotesis dalam penelitian ini terdiri dari uji linearitas dan uji multikolinearitas.

1) Uji Linearitas

Uji linearitas dilakukan untuk mengetahui variabel bebas $(\mathrm{X})$ dan variabel terikat (Y) memiliki hubungan yang linier atau tidak. Hubungan antara variabel bebas terhadap variabel terikat dikatakan linier apabila $F_{\text {hitung }}<F_{\text {tabel }}$. Sebaliknya, jika $F_{\text {hitung }}>F_{\text {tabel }}$ maka data dikatakan tidak linier pada taraf signifikansi $5 \%$.

2) Uji Multikolinearitas

Uji multikolinearitas digunakan untuk mengetahui ada tidaknya multikolinearitas antar variabel bebas. Menurut Nugroho (2005: 58), jika nilai korelasi > 0,70 maka terjadi multikolinearitas, sebaliknya apabila nilai korelasi $<0,70$ tidak terjadi multikolinearitas antar variabel sehingga analisis regresi ganda dapat dilanjutkan.

b. Uji Hipotesis

Uji hipotesis dalam penelitian ini menggunakan analisis regresi sederhana dan analisis regresi ganda. Analisis regresi sederhana digunakan untuk pengujian hipotesis pertama yaitu terdapat pengaruh positif Pengalaman Praktik Kerja Industri terhadap Kesiapan Kerja Siswa Kelas XII Akuntansi SMK N 1 Pengasih Tahun Ajaran 2018/2019, hipotesis kedua yaitu terdapat pengaruh positif Informasi Dunia Kerja terhadap Kesiapan Kerja Siswa Kelas XII Akuntansi SMK N 1 Pengasih Tahun Ajaran 2018/2019, dan hipotesis ketiga yaitu terdapat pengaruh positif Motivasi Memasuki Dunia Kerja terhadap Kesiapan Kerja Siswa Kelas XII Akuntansi SMK N 1 Pengasih Tahun Ajaran 2018/2019. Analisis regresi ganda digunakan untuk pengujian hipotesis keempat, yaitu terdapat pengaruh positif Pengalaman Praktik Kerja Industri, Informasi Dunia Kerja, dan Motivasi Memasuki Dunia Kerja secara bersama-sama terhadap Kesiapan Kerja Siswa Kelas XII Akuntansi SMK N 1 Pengasih Tahun Ajaran 2018/2019.
HASIL
PENELITIAN
DAN

\section{PEMBAHASAN}
Uji Prasyarat Analisis
a. Uji Linearitas
Hasil uji linearitas dengan bantuan program statistik, sebagai berikut. 


\begin{tabular}{|c|c|c|c|c|c|}
\hline \multicolumn{2}{|c|}{ Tabel 3.} & \multicolumn{2}{|c|}{$\begin{array}{l}\text { Ringkasan } \\
\text { Linearitas }\end{array}$} & Hasil & Uji \\
\hline $\begin{array}{c}\text { Varia- } \\
\text { bel } \\
\text { bebas }\end{array}$ & $D f$ & $\begin{array}{c}\mathbf{F} \\
\text { hitung }\end{array}$ & $\mathbf{F}_{\text {tabel }}$ & Sig & Ket \\
\hline $\mathrm{X}_{1}$ & $22 / 40$ & 1,342 & 1,814 & 0,205 & Linier \\
\hline $\mathrm{X}_{2}$ & $15 / 47$ & 1,041 & 1,885 & 0,433 & Linier \\
\hline $\mathrm{X}_{3}$ & $18 / 44$ & \begin{tabular}{|l|l}
1,730 \\
\end{tabular} & 1,844 & 0,070 & Linier \\
\hline
\end{tabular}

Berdasarkan Tabel 3 tersebut dapat diketahui harga $F_{\text {hitung }}$ dari perhitungan masing-masing variabel lebih kecil dari $F_{\text {tabel }}$ pada taraf signifikansi 5\%, sehingga semua pola hubungan variabel bebas dengan variabel terikat bersifat linier.

b. Uji Multikolinearitas

Hasil uji multikolinearitas dengan bantuan program statistik, sebagai berikut.

Tabel 4. Ringkasan Hasil Multikolinearitas dengan Korelasi Product Moment

\begin{tabular}{|c|c|c|c|c|}
\hline \multirow{2}{*}{$\begin{array}{c}\text { Variab } \\
\text { el } \\
\text { Bebas }\end{array}$} & \multicolumn{3}{|c|}{$\begin{array}{c}\text { Koefisien } \\
\text { Korelasi }\end{array}$} & \multirow[t]{2}{*}{ Keterangan } \\
\hline & $\mathbf{X}_{1}$ & $\mathbf{X}_{2}$ & $\mathbf{X}_{3}$ & \\
\hline \multirow{2}{*}{$\mathrm{X}_{1}$} & 1,00 & 0,54 & 0,48 & \multirow{6}{*}{$\begin{array}{c}\text { Ketiga } \\
\text { variabel tidak } \\
\text { terjadi } \\
\text { multikolinear } \\
\text { itas antar } \\
\text { variabel } \\
\text { bebas. }\end{array}$} \\
\hline & 0 & 8 & 6 & \\
\hline \multirow{2}{*}{$\mathrm{X}_{2}$} & 0,54 & 1,00 & 0,43 & \\
\hline & 8 & 0 & 4 & \\
\hline \multirow{2}{*}{$X_{3}$} & 0,48 & 0,43 & 1,00 & \\
\hline & 6 & 4 & 0 & \\
\hline
\end{tabular}

Berdasarkan Tabel 4 tersebut, dapat diketahui bahwa ketiga variabel bebas tidak terjadi multikolinearitas karena nilai korelasi antar variabel $<0,70$.

\section{Uji Hipotesis}

a. Uji Hipotesis Pertama

Hasil analisis regresi sederhana hipotesis pertama dapat dilihat pada tabel sebagai berikut.
Tabel 5. Ringkasan Hasil Uji Hipotesis Pertama $\left(\mathbf{X}_{1}-\mathbf{Y}\right)$

\begin{tabular}{|c|c|c|c|c|c|c|c|}
\hline \multicolumn{2}{|c|}{$\begin{array}{c}\text { Harga } r- \\
\mathbf{r}^{2}\end{array}$} & \multirow{2}{*}{$\begin{array}{l}t_{\text {hit }} \\
\text { ung }\end{array}$} & \multirow{2}{*}{$\begin{array}{l}\mathbf{t}_{\mathrm{ta}} \\
\text { bel }\end{array}$} & \multirow{2}{*}{$\begin{array}{c}\text { Ko } \\
\text { ef }\end{array}$} & \multirow{2}{*}{$\begin{array}{l}\text { Kons } \\
\text { tanta }\end{array}$} & \multirow[t]{2}{*}{ Sig } & \multirow[t]{2}{*}{ Ket } \\
\hline $\mathbf{r}_{\mathrm{x} 1 \mathrm{y}}$ & $\mathbf{r}^{2} \times 1 y$ & & & & & & \\
\hline 0 , & 0,64 & 10 & 1, & 0,58 & 11,67 & 0,0 & Posi \\
\hline 80 & 2 & 550 & 67 & 2 & 9 & 00 & tif \\
\hline 1 & & & 0 & & & & \\
\hline
\end{tabular}

Berdasarkan Tabel 5 tersebut, dapat diketahui bahwa koefisien korelasi ( $\left.\mathrm{r}_{\mathrm{x} 1 \mathrm{y}}\right)$ sebesar 0,801 . Koefisien korelasi yang bernilai positif tersebut menunjukkan bahwa terdapat hubungan positif Pengalaman Praktik Kerja Industri terhadap Kesiapan Kerja siswa kelas XII Akuntansi SMK N 1 Pengasih Tahun Ajaran 2018/2019. Dengan demikian, dapat dikatakan bahwa semakin tinggi Pengalaman Praktik Kerja Industri $\left(\mathrm{X}_{1}\right)$, maka semakin tinggi pula Kesiapan Kerja (Y). Koefisien determinasi $\mathrm{X}_{1}$ terhadap $\mathrm{Y}$ $\left(r^{2}{ }^{x} 1 y\right)$ sebesar 0,642. Hal tersebut menunjukkan bahwa Pengalaman Praktik Kerja Industri $\left(\mathrm{X}_{1}\right)$ mampu mempengaruhi $64,2 \%$ perubahan pada Kesiapan Kerja (Y), selebihnya sebesar $35,8 \%$ dipengaruhi oleh variabel lain. Besarnya koefisien Pengalaman Praktik Kerja Industri $\left(\mathrm{X}_{1}\right)$ sebesar 0,582 dan bilangan konstanta sebesar 11,679, maka persamaan garis regresi dinyatakan dalam persamaan $\mathrm{Y}=$ $0,582 X_{1}+11,679$. Persamaan tersebut menunjukkan bahwa nilai koefisien regresi bernilai positif sebesar 0,582, yang berarti jika Pengalaman Praktik Kerja Industri $\left(\mathrm{X}_{1}\right)$ meningkat satu satuan maka Kesiapan Kerja (Y) akan meningkat sebesar 0,582. Hasil uji $t$ dengan uji satu fihak dan taraf signifikansi $5 \%$ diperoleh $t_{\text {hitung }}$ sebesar 10,550 lebih besar dari $t_{\text {tabel }}$ sebesar 1,670 , sehingga hipotesis pertama yang menyatakan bahwa "Terdapat pengaruh positif Pengalaman Praktik Kerja Industri terhadap Kesiapan Kerja siswa 
kelas XII Akuntansi SMK N 1 Pengasih Tahun Ajaran 2018/2019” diterima.

b. Uji Hipotesis Kedua

Hasil analisis regresi sederhana hipotesis kedua dapat dilihat pada tabel sebagai berikut.

Tabel 6. Ringkasan Hasil Uji Hipotesis Kedua $\left(\mathrm{X}_{2}-\mathbf{Y}\right)$

\begin{tabular}{|c|c|c|c|c|c|c|c|}
\hline \multicolumn{2}{|c|}{$\begin{array}{c}\text { Harga } \mathbf{r}- \\
\mathbf{r}^{2}\end{array}$} & & \multirow[t]{2}{*}{$\mathbf{t}_{\text {tabel }}$} & \multirow{2}{*}{$\begin{array}{c}\text { Ko } \\
\text { ef }\end{array}$} & \multirow{2}{*}{$\begin{array}{l}\text { Kons } \\
\text { tanta }\end{array}$} & \multirow[t]{2}{*}{ Sig } & \multirow{2}{*}{$\begin{array}{c}\text { Ket } \\
\text {. }\end{array}$} \\
\hline $\mathbf{r}_{\mathrm{x} 2 \mathrm{y}}$ & $\mathbf{r}_{\mathrm{x} 2 \mathrm{y}}^{2}$ & & & & & & \\
\hline 0,6 & 0,43 & 6,94 & 1,6 & 0,7 & 24,24 & 0,00 & Posi \\
\hline 61 & 7 & 0 & 70 & 85 & 7 & 0 & tif \\
\hline
\end{tabular}

Berdasarkan Tabel 6 di atas, dapat diketahui bahwa koefisien korelasi $\left(\mathrm{r}_{\mathrm{x} 2 \mathrm{y}}\right)$ sebesar 0,661. Koefisien korelasi yang bernilai positif tersebut menunjukkan bahwa terdapat hubungan positif Informasi Dunia Kerja terhadap Kesiapan Kerja siswa kelas XII Akuntansi SMK N 1 Pengasih Tahun Ajaran 2018/2019. Dengan demikian, dapat dikatakan bahwa semakin tinggi Informasi Dunia Kerja $\left(\mathrm{X}_{2}\right)$, maka semakin tinggi pula Kesiapan Kerja (Y). Koefisien determinasi $\mathrm{X}_{2}$ terhadap $Y\left(r^{2} x 2 y\right)$ sebesar 0,437 . Hal tersebut menunjukkan bahwa Informasi Dunia Kerja $\left(\mathrm{X}_{2}\right)$ mampu mempengaruhi 43,7\% perubahan pada Kesiapan Kerja (Y), selebihnya sebesar 56,3\% dipengaruhi oleh variabel lain. Besarnya koefisien Informasi Dunia Kerja $\left(\mathrm{X}_{2}\right)$ sebesar 0,785 dan bilangan konstanta sebesar 24,247, maka persamaan garis regresi dinyatakan dalam persamaan $\mathrm{Y}=0,785 \mathrm{X}_{2}+$ 24,247. Persamaan tersebut menunjukkan bahwa nilai koefisien regresi bernilai positif sebesar 0,785 , yang berarti jika Informasi Dunia Kerja $\left(\mathrm{X}_{2}\right)$ meningkat satu satuan maka Kesiapan Kerja (Y) akan meningkat sebesar 0,785. Hasil uji t dengan uji satu fihak dan taraf signifikansi 5\% diperoleh thitung sebesar 6,940 lebih besar dari tabel sebesar 1,670, sehingga hipotesis kedua yang berbunyi "Terdapat pengaruh positif Informasi Dunia Kerja terhadap Kesiapan Kerja siswa kelas XII Akuntansi SMK N 1 Pengasih Tahun Ajaran 2018/2019" diterima.

\section{c. Uji Hipotesis Ketiga}

Hasil analisis regresi sederhana hipotesis ketiga dapat dilihat pada tabel sebagai berikut.

Tabel 7. Ringkasan Hasil Uji Hipotesis Ketiga $\left(\mathbf{X}_{3}-\mathbf{Y}\right)$

\begin{tabular}{|c|c|c|c|c|c|c|c|}
\hline \multicolumn{2}{|c|}{ Harga $r-r^{2}$} & \multirow[b]{2}{*}{$\begin{array}{c}\mathbf{t}_{\text {hitu }} \\
\text { ng }\end{array}$} & \multirow[b]{2}{*}{ ttabel } & \multirow[b]{2}{*}{$\begin{array}{c}\text { Koe } \\
\mathbf{f}\end{array}$} & \multirow{2}{*}{$\begin{array}{l}\text { Ko } \\
\text { nst } \\
\text { nta }\end{array}$} & \multirow[b]{2}{*}{ Sig } & \multirow[b]{2}{*}{$\begin{array}{c}\text { Ket } \\
\text {. }\end{array}$} \\
\hline $\mathbf{r}_{\mathbf{x} 3 \mathrm{y}}$ & $\mathbf{r}^{2} \times 3 y$ & & & & & & \\
\hline 0,52 & 0,27 & 4,81 & 1,67 & 0,5 & 27,4 & 0,00 & Posi \\
\hline 2 & 2 & 9 & 0 & 82 & 82 & 0 & tif \\
\hline
\end{tabular}

Berdasarkan Tabel 7 di atas, dapat diketahui bahwa koefisien korelasi $\left(\mathrm{r}_{\mathrm{x} 3 \mathrm{y}}\right)$ sebesar 0,522. Koefisien korelasi yang bernilai positif tersebut menunjukkan bahwa terdapat hubungan positif Motivasi Memasuki Dunia Kerja terhadap Kesiapan Kerja siswa kelas XII Akuntansi SMK N 1 Pengasih Tahun Ajaran 2018/2019. Dengan demikian, dapat dikatakan bahwa semakin tinggi Motivasi Memasuki Dunia Kerja $\left(\mathrm{X}_{3}\right)$, maka semakin tinggi pula Kesiapan Kerja (Y). Koefisien determinasi $\mathrm{X}_{3}$ terhadap $\mathrm{Y} \quad\left(\mathrm{r}^{2} \mathrm{x3y}\right)$ sebesar 0,272. Hal tersebut menunjukkan bahwa Motivasi Memasuki Dunia Kerja ( $\left.\mathrm{X}_{3}\right)$ mampu mempengaruhi $27,2 \%$ perubahan pada Kesiapan Kerja (Y), selebihnya sebesar $72,8 \%$ dipengaruhi oleh variabel lain. Besarnya koefisien Motivasi Memasuki Dunia Kerja $\left(\mathrm{X}_{3}\right)$ sebesar 0,582 dan bilangan konstanta sebesar 27,482, maka persamaan garis regresi dinyatakan dalam persamaan $\mathrm{Y}=$ $0,582 X_{3}+27,482$. Persamaan tersebut menunjukkan bahwa nilai koefisien regresi bernilai positif sebesar 0,582 , 
yang berarti jika Motivasi Memasuki Dunia Kerja $\left(\mathrm{X}_{3}\right)$ meningkat satu satuan maka Kesiapan Kerja (Y) akan meningkat sebesar 0,582. Hasil uji $\mathrm{t}$ dengan uji satu fihak dan taraf signifikansi $5 \%$ diperoleh $t_{\text {hitung }}$ sebesar 4,819 lebih besar dari $t_{\text {tabel }}$ sebesar 1,670, sehingga hipotesis ketiga yang menyatakan bahwa "Terdapat pengaruh positif Motivasi Memasuki Dunia Kerja terhadap Kesiapan Kerja siswa kelas XII Akuntansi SMK N 1 Pengasih Tahun Ajaran 2018/2019” diterima.

d. Uji Hipotesis Keempat

Hasil analisis regresi ganda hipotesis keempat dapat dilihat pada tabel sebagai berikut.

Tabel 8. Ringkasan Hasil Uji Hipotesis Keempat $\left(\mathbf{X}_{1}, \mathbf{X}_{2}, \mathbf{X}_{3}-\mathbf{Y}\right)$

\begin{tabular}{|c|c|c|c|c|c|c|c|}
\hline \multicolumn{2}{|c|}{ Harga R-R ${ }^{2}$} & \multirow[b]{2}{*}{$\begin{array}{c}\text { Fhit }_{\text {ung }} \\
\text { un }\end{array}$} & \multirow[b]{2}{*}{$\begin{array}{c}F_{\text {ta }} \\
\text { bel }\end{array}$} & \multirow[b]{2}{*}{ Koef } & \multirow[b]{2}{*}{$\begin{array}{l}\text { Kons } \\
\text { tanta }\end{array}$} & \multirow[b]{2}{*}{ Sig } & \multirow[b]{2}{*}{ Ket. } \\
\hline $\begin{array}{c}\mathbf{R}_{\mathbf{y}} \\
(\mathbf{1 , 2 , 3 )})\end{array}$ & $\begin{array}{c}R^{2} y \\
(1,2,3)\end{array}$ & & & & & & \\
\hline \multirow{3}{*}{$\begin{array}{c}0,84 \\
9\end{array}$} & \multirow{3}{*}{$\begin{array}{c}0,72 \\
2\end{array}$} & \multirow{3}{*}{$\begin{array}{c}51,8 \\
31\end{array}$} & \multirow{3}{*}{2,76} & 0,428 & \multirow{3}{*}{2,984} & \multirow{3}{*}{$\begin{array}{c}0,00 \\
0\end{array}$} & \multirow{3}{*}{$\begin{array}{c}\text { Posi } \\
\text { tif }\end{array}$} \\
\hline & & & & 0,346 & & & \\
\hline & & & & 0,122 & & & \\
\hline
\end{tabular}

Berdasarkan Tabel 8 di atas, dapat diketahui bahwa koefisien korelasi $\left(\mathrm{R}_{\mathrm{y}(1,2,3)}\right) \quad$ sebesar 0,849. Koefisien korelasi yang bernilai positif tersebut menunjukkan bahwa terdapat hubungan positif Pengalaman Praktik Kerja Industri, Informasi Dunia Kerja, dan Motivasi Memasuki Dunia Kerja secara bersama-sama terhadap Kesiapan Kerja siswa kelas XII Akuntansi SMK N 1 Pengasih Tahun Ajaran 2018/2019. Dengan demikian, dapat dikatakan bahwa semakin tinggi Pengalaman Praktik Kerja Industri $\left(\mathrm{X}_{1}\right)$, Informasi Dunia Kerja $\left(\mathrm{X}_{2}\right)$, dan Motivasi Memasuki Dunia Kerja $\left(\mathrm{X}_{3}\right)$, maka semakin tinggi pula Kesiapan Kerja (Y). Koefisien determinasi $\mathrm{X}_{1}, \mathrm{X}_{2}$ dan $\mathrm{X}_{3}$ terhadap $\mathrm{Y}\left(\mathrm{R}_{\mathrm{y}(1,2,3)}^{2}\right)$ sebesar 0,722 . Hal tersebut menunjukkan bahwa Pengalaman Praktik Kerja Industri $\left(\mathrm{X}_{1}\right)$, Informasi Dunia Kerja $\left(\mathrm{X}_{2}\right)$, dan
Motivasi Memasuki Dunia Kerja $\left(\mathrm{X}_{3}\right)$ secara bersama-sama mampu mempengaruhi $72,2 \%$ perubahan pada Kesiapan Kerja (Y), selebihnya sebesar $27,8 \%$ dipengaruhi oleh variabel lain. Besarnya koefisien Pengalaman Praktik Kerja Industri $\left(\mathrm{X}_{1}\right)$ sebesar 0,428, koefisien Informasi Dunia Kerja $\left(\mathrm{X}_{2}\right)$ sebesar 0,346, koefisien Motivasi Memasuki Dunia Kerja $\left(\mathrm{X}_{3}\right)$ sebesar 0,122, dan bilangan konstanta sebesar 2,984, maka persamaan garis regresi dinyatakan dalam persamaan $\mathrm{Y}=$ $0,428 X_{1}+0,346 X_{2}+0,122 X_{3}+2,984$. Persamaan tersebut menunjukkan bahwa nilai koefisien regresi $\mathrm{X}_{1}$ bernilai positif sebesar 0,428, yang berarti jika Pengalaman Praktik Kerja Industri $\left(\mathrm{X}_{1}\right)$ meningkat satu satuan maka Kesiapan Kerja (Y) akan meningkat sebesar 0,428 dengan asumsi $\mathrm{X}_{2}$ dan $\mathrm{X}_{3}$ tetap, nilai koefisien regresi $\mathrm{X}_{2}$ sebesar 0,346 yang berarti Informasi Dunia Kerja $\left(\mathrm{X}_{2}\right)$ meningkat satu satuan maka Kesiapan Kerja (Y) akan meningkat sebesar 0,346 dengan asumsi $X_{1}$ dan $X_{3}$ tetap, demikian pula nilai koefisien regresi $\mathrm{X}_{3}$ sebesar 0,122 yang berarti jika Motivasi Memasuki Dunia Kerja $\left(\mathrm{X}_{3}\right)$ meningkat satu satuan maka Kesiapan Kerja (Y) akan meningkat sebesar 0,122 dengan asumsi $\mathrm{X}_{1}$ dan $\mathrm{X}_{2}$ tetap. Nilai $F_{\text {hitung }}$ sebesar 51,831 kemudian dibandingkan dengan $\mathrm{F}_{\text {tabel }}$ pada taraf signifikansi 5\% yaitu sebesar 2,76. Hal tersebut menunjukkan bahwa $F_{\text {hitung }}(51,831)>$ $F_{\text {tabel }}(2,76)$, sehingga hipotesis keempat yang berbunyi "Terdapat pengaruh positif Pengalaman Praktik Kerja Industri, Informasi Dunia Kerja, dan Motivasi Memasuki Dunia Kerja secara bersama-sama terhadap Kesiapan Kerja siswa kelas XII Akuntansi SMK N 1 Pengasih Tahun Ajaran 2018/2019" diterima.

e. Sumbangan Relatif dan Sumbangan Efektif 
Berdasarkan hasil analisis regresi ganda, dapat diketahui besarnya Sumbangan Relatif dan Sumbangan Efektif masing-masing variabel bebas (Pengalaman Praktik Kerja Industri, Informasi Dunia Kerja, dan Motivasi Memasuki Dunia Kerja) terhadap variabel terikat (Kesiapan Kerja) yang diteliti, sebagai berikut.

Tabel 9. Hasil Sumbangan Relatif (SR)

\begin{tabular}{|c|c|c|}
\hline No. & $\begin{array}{c}\text { Nama Variabel } \\
\text { Bebas }\end{array}$ & $\begin{array}{l}\text { Sumbangan } \\
\text { Relatif (SR) }\end{array}$ \\
\hline 1. & $\mathrm{X}_{1}$ & $61,73 \%$ \\
\hline 2. & $\mathrm{X}_{2}$ & $26,80 \%$ \\
\hline 3. & $\mathrm{X}_{3}$ & $11,47 \%$ \\
\hline & Jumlah & $100,00 \%$ \\
\hline
\end{tabular}

Berdasarkan Tabel 9 tersebut, dapat diketahui bahwa Sumbangan Relatif (SR) untuk variabel Pengalaman Praktik Kerja Industri terhadap Kesiapan Kerja sebesar 61,73\%, variabel Informasi Dunia Kerja terhadap Kesiapan Kerja sebesar 26,80\%, dan variabel Motivasi Memasuki Dunia Kerja terhadap Kesiapan Kerja sebesar 11,47\%.

Tabel 10. Hasil Sumbangan Efektif (SE)

\begin{tabular}{|c|c|c|}
\hline No. & $\begin{array}{c}\text { Nama Variabel } \\
\text { Bebas }\end{array}$ & $\begin{array}{c}\text { Sumbangan } \\
\text { Efektif (SE) }\end{array}$ \\
\hline 1. & $\mathrm{X}_{1}$ & $44,57 \%$ \\
\hline 2. & $\mathrm{X}_{2}$ & $19,35 \%$ \\
\hline 3. & $\mathrm{X}_{3}$ & $8,28 \%$ \\
\hline \multicolumn{3}{|c}{ Jumlah } \\
\hline
\end{tabular}

Dari Tabel 10 di atas, dapat diketahui bahwa variabel Pengalaman Praktik Kerja Industri, Informasi Dunia Kerja, dan Motivasi Memasuki Dunia Kerja secara bersama-sama memberikan Sumbangan Efektif (SE) sebesar 72,20\% terhadap Kesiapan Kerja, sedangkan sebesar 27,80\% diberikan oleh variabel lain yang tidak diteliti dalam penelitian ini.

\section{Pembahasan}

a. Pengaruh Pengalaman Praktik Kerja Industri terhadap Kesiapan Kerja Siswa Kelas XII Akuntansi SMK N 1 Pengasih Tahun Ajaran 2018/2019

Hasil penelitian ini menunjukkan bahwa terdapat pengaruh positif Pengalaman Praktik Kerja Industri terhadap Kesiapan Kerja Siswa Kelas XII Akuntansi SMK N 1 Pengasih Tahun Ajaran 2018/2019. Berdasarkan hasil analisis regresi sederhana diperoleh persamaan garis regresi dengan satu prediktor $\mathrm{Y}=0,582 \mathrm{X}_{1}+$ 11,679, harga koefisien korelasi $\left(\mathrm{r}_{\mathrm{x} 1 \mathrm{y}}\right)$ sebesar 0,801, dan harga koefisien determinasi $\left(\mathrm{r}^{2}{ }_{\mathrm{x} 1 \mathrm{y}}\right)$ sebesar 0,642 dengan taraf signifikansi 5\%, yang artinya bahwa Pengalaman Praktik Kerja Industri memberikan pengaruh positif terhadap Kesiapan Kerja sebesar 64,2\% dan selebihnya sebesar $35,8 \%$ dipengaruhi oleh faktor lain. Hasil uji t diperoleh $t_{\text {hitung }}>t_{\text {tabel }}(10,550>1,670)$.

Hasil penelitian ini sejalan dengan teori yang dikemukakan oleh Kardimin (2004: 2-9) bahwa faktor-faktor yang mempengaruhi Kesiapan Kerja diantaranya adalah faktor eksternal yang salah satunya yaitu pengalaman kerja. Pengalaman kerja dalam penelitian ini yaitu Pengalaman Praktik Kerja Industri. Jika siswa telah memiliki Pengalaman Praktik Kerja Industri, maka siswa tersebut akan siap terjun ke dunia kerja ketika lulus dari sekolah nanti, karena pada dasarnya siswa SMK dicetak untuk siap bekerja. Ketika Pengalaman Praktik Kerja Industri yang dimilikinya kurang atau tidak sesuai dengan bidang keahliannya, maka Kesiapan Kerja dalam bidangnya juga menjadi kurang. Jadi, Pengalaman Praktik Kerja Industri yang cukup akan meningkatkan Kesiapan Kerja siswa.

b. Pengaruh Informasi Dunia Kerja terhadap Kesiapan Kerja Siswa Kelas 
XII Akuntansi SMK N 1 Pengasih Tahun Ajaran 2018/2019

Hasil penelitian ini menunjukkan bahwa terdapat pengaruh positif Informasi Dunia Kerja terhadap Kesiapan Kerja Siswa Kelas XII Akuntansi SMK N 1 Pengasih Tahun Ajaran 2018/2019. Berdasarkan hasil analisis regresi sederhana diperoleh persamaan garis regresi dengan satu prediktor $\mathrm{Y}=0,785 \mathrm{X}_{2}+24,247$, harga koefisien korelasi $\left(\mathrm{r}_{\mathrm{x} 2 \mathrm{y}}\right)$ sebesar 0,661, dan harga koefisien determinasi $\left(\mathrm{r}_{\mathrm{x} 2 \mathrm{y}}^{2}\right)$ sebesar 0,437 dengan taraf signifikansi $5 \%$, yang artinya bahwa Informasi Dunia Kerja memberikan pengaruh positif terhadap Kesiapan Kerja sebesar $43,7 \%$ dan selebihnya sebesar 56,3\% dipengaruhi oleh faktor lain. Hasil uji $\mathrm{t}$ diperoleh $t_{\text {hitung }}>t_{\text {tabel }}(6,940>1,670)$.

Hasil penelitian ini sejalan dengan teori yang dikemukakan oleh Kardimin (2004: 2-9) bahwa faktor-faktor yang mempengaruhi Kesiapan Kerja diantaranya adalah faktor eksternal yang salah satunya yaitu Informasi Dunia Kerja. Informasi Dunia Kerja ini sangat penting bagi lulusan SMK khususnya informasi yang sesuai dengan bidang keahliannya, karena siswa lulusan SMK akan mencari pekerjaan sesuai dengan bidangnya. Informasi Dunia Kerja dapat memberikan gambaran mengenai bagaimana pekerjaan yang sedang ditawarkan oleh lembaga atau perusahaan tertentu dan apa yang harus dikerjakan beserta persyaratannya. Jika siswa sudah mengetahui Informasi Dunia Kerja tersebut, maka ia akan memiliki Kesiapan Kerja.

c. Pengaruh Motivasi Memasuki Dunia Kerja terhadap Kesiapan Kerja Siswa Kelas XII Akuntansi SMK N 1 Pengasih Tahun Ajaran 2018/2019

Hasil penelitian ini menunjukkan bahwa terdapat pengaruh positif
Motivasi Memasuki Dunia Kerja terhadap Kesiapan Kerja Siswa Kelas XII Akuntansi SMK N 1 Pengasih Tahun Ajaran 2018/2019. Berdasarkan hasil analisis regresi sederhana diperoleh persamaan garis regresi dengan satu prediktor $\mathrm{Y}=0,582 \mathrm{X}_{3}+$ 27,482 , harga koefisien korelasi $\left(\mathrm{r}_{\mathrm{x} 3 \mathrm{y}}\right)$ sebesar 0,522, dan harga koefisien determinasi $\left(\mathrm{r}^{2} \times 3 \mathrm{y}\right)$ sebesar 0,272 dengan taraf signifikansi 5\%, yang artinya bahwa Motivasi Memasuki Dunia Kerja memberikan pengaruh positif terhadap Kesiapan Kerja sebesar 27,2\% dan selebihnya sebesar $72,8 \%$ dipengaruhi oleh faktor lain. Hasil uji t diperoleh $t_{\text {hitung }}>t_{\text {tabel }}(4,819>1,670)$.

Hasil penelitian ini sejalan dengan teori yang dikemukakan oleh Kardimin (2004: 2-9) bahwa faktor-faktor yang mempengaruhi Kesiapan Kerja diantaranya adalah faktor internal yang salah satunya yaitu motivasi. Motivasi dalam penelitian ini yaitu Motivasi Memasuki Dunia Kerja. Jika siswa memiliki kemauan dan kemampuan untuk segera bekerja, maka dari dalam diri siswa tersebut sudah timbul adanya Motivasi Memasuki Dunia Kerja. Motivasi Memasuki Dunia Kerja ini timbul karena adanya hasrat dan keinginan untuk memasuki dunia kerja, adanya harapan dan cita-cita masa depan, adanya desakan dan dorongan dari lingkungan, adanya kebutuhan fisiologis, dan adanya penghormatan atas diri. Jika Motivasi Memasuki Dunia Kerja tinggi, maka siswa akan membekali dirinya dengan berbagai kompetensi dan keterampilan yang akan digunakan saat bekerja nanti, sehingga ia siap untuk terjun ke dunia kerja.

d. Pengaruh Pengalaman Praktik Kerja Industri, Informasi Dunia Kerja, dan Motivasi Memasuki Dunia Kerja secara bersama-sama terhadap Kesiapan Kerja 
Siswa Kelas XII Akuntansi SMK N 1 Pengasih Tahun Ajaran 2018/2019

Hasil penelitian ini menunjukkan bahwa terdapat pengaruh positif Pengalaman Praktik Kerja Industri, Informasi Dunia Kerja, dan Motivasi Memasuki Dunia Kerja secara bersamasama terhadap Kesiapan Kerja Siswa Kelas XII Akuntansi SMK N 1 Pengasih Tahun Ajaran 2018/2019. Berdasarkan hasil analisis regresi ganda diperoleh persamaan garis regresi dengan tiga prediktor $\mathrm{Y}=0,428 \mathrm{X}_{1}+$ $0,346 X_{2}+0,122 X_{3}+2,984$, harga koefisien korelasi $\left(\mathrm{R}_{\mathrm{y}(1,2,3)}\right)$ sebesar 0,849 , dan harga koefisien determinasi $\left(\mathrm{R}_{\mathrm{y}(1,2,3)}^{2}\right)$ sebesar 0,722 dengan taraf signifikansi $5 \%$, yang artinya bahwa Pengalaman Praktik Kerja Industri, Informasi Dunia Kerja, dan Motivasi Memasuki Dunia Kerja secara bersamasama memberikan pengaruh positif terhadap Kesiapan Kerja sebesar 72,2\% dan selebihnya sebesar $27,8 \%$ dipengaruhi oleh faktor lain yang tidak diteliti dalam penelitian ini. Hasil uji $\mathrm{F}$ diperoleh $F_{\text {hitung }}>F_{\text {tabel }}(51,831>2,76)$. Sumbangan Relatif (SR) variabel Pengalaman Praktik Kerja Industri sebesar 61,73\%, variabel Informasi Dunia Kerja sebesar 26,80\%, dan variabel Motivasi Memasuki Dunia Kerja sebesar $11,47 \%$. Jadi, total Sumbangan Relatif (SR) yaitu sebesar $100 \%$. Sumbangan Efektif (SE) variabel Pengalaman Praktik Kerja Industri sebesar 44,57\%, variabel Informasi Dunia Kerja sebesar 19,35\%, dan variabel Motivasi Memasuki Dunia Kerja sebesar 8,28\%. Jadi, total Sumbangan Efektif (SE) yaitu sebesar $72,20 \%$, sedangkan selebihnya sebesar $27,80 \%$ diberikan oleh variabel lain yang tidak diteliti dalam penelitian ini. Berdasarkan penelitian tersebut, maka semakin tinggi Pengalaman Praktik Kerja Industri, Informasi Dunia Kerja, dan Motivasi Memasuki Dunia Kerja, maka akan semakin tinggi pula Kesiapan Kerja Siswa Kelas XII Akuntansi SMK N 1 Pengasih Tahun Ajaran 2018/2019.

\section{SIMPULAN DAN SARAN \\ Simpulan}

Berdasarkan pembahasan yang telah diuraikan sebelumnya, maka dapat ditarik kesimpulan, sebagai berikut.

a. Terdapat pengaruh positif Pengalaman Praktik Kerja Industri terhadap Kesiapan Kerja Siswa Kelas XII Akuntansi SMK N 1 Pengasih Tahun Ajaran 2018/2019. Hal ini ditunjukkan dengan koefisien korelasi $\left(\mathrm{r}_{\mathrm{x} 1 \mathrm{y}}\right)$ sebesar 0,801 , koefisien determinasi $\left(\mathrm{r}^{2}{ }_{\mathrm{x} 1 \mathrm{y}}\right)$ sebesar 0,642 dengan taraf signifikansi $5 \%$. Persamaan garis regresi sederhana $Y=0,582 X_{1}+11,679$. Hasil uji $t$ diperoleh $t_{\text {hitung }}>t_{\text {tabel }}(10,550$ $>1,670)$, sehingga hipotesis pertama diterima.

b. Terdapat pengaruh positif Informasi Dunia Kerja terhadap Kesiapan Kerja Siswa Kelas XII Akuntansi SMK N 1 Pengasih Tahun Ajaran 2018/2019. Hal ini dibuktikan dengan koefisien korelasi $\left(r_{\mathrm{x} 2 \mathrm{y}}\right) \quad$ sebesar 0,661, koefisien determinasi $\left(\mathrm{r}^{2} \times 2 \mathrm{y}\right)$ sebesar 0,437 dengan taraf signifikansi 5\%. Persamaan regresi sederhana $\mathrm{Y}=0,785 \mathrm{X}_{2}+24,247$. Hasil uji $\mathrm{t}$ diperoleh $\mathrm{t}_{\text {hitung }}>\mathrm{t}_{\text {tabel }}(6,940>$ 1,670), sehingga hipotesis kedua diterima.

c. Terdapat pengaruh positif Motivasi Memasuki Dunia Kerja terhadap Kesiapan Kerja Siswa Kelas XII Akuntansi SMK N 1 Pengasih Tahun Ajaran 2018/2019. Hal tersebut ditunjukkan oleh koefisien korelasi $\left(\mathrm{r}_{\mathrm{x} 3 \mathrm{y}}\right)$ sebesar 0,522, koefisien determinasi $\left(r^{2} \times 3 y\right)$ sebesar 0,272 dengan taraf signifikansi 5\%. Persamaan garis regresi sederhana $\mathrm{Y}=0,582 \mathrm{X}_{3}+27,482$. Hasil uji $\mathrm{t}$ diperoleh $\mathrm{t}_{\text {hitung }}>\mathrm{t}_{\text {tabel }}(4,819>$ 1,670), sehingga hipotesis ketiga diterima. 
d. Terdapat pengaruh positif Pengalaman Praktik Kerja Industri, Informasi Dunia Kerja, dan Motivasi Memasuki Dunia Kerja secara bersama-sama terhadap Kesiapan Kerja Siswa Kelas XII Akuntansi SMK N 1 Pengasih Tahun Ajaran 2018/2019. Hal tersebut dibuktikan dengan koefisien korelasi $\left(\mathrm{R}_{\mathrm{y}(1,2,3)}\right) \quad$ sebesar 0,849 , koefisien determinasi $\left(\mathrm{R}_{\mathrm{y}(1,2,3)}^{2}\right)$ sebesar 0,722 dengan taraf signifikansi 5\%. Persamaan garis regresi ganda $\mathrm{Y}=0,428 \mathrm{X}_{1}+$ $0,346 X_{2}+0,122 X_{3}+2,984$. Hasil uji $F$ diperoleh $F_{\text {hitung }}>F_{\text {tabel }}(51,831>2,76)$, sehingga hipotesis keempat diterima. Sumbangan Relatif (SR) variabel Pengalaman Praktik Kerja Industri sebesar 61,73\%, variabel Informasi Dunia Kerja sebesar 26,80\%, dan variabel Motivasi Memasuki Dunia Kerja sebesar 11,47\%. Jadi, total Sumbangan Relatif (SR) yaitu sebesar $100 \%$. Sumbangan Efektif (SE) variabel Pengalaman Praktik Kerja Industri sebesar 44,57\%, variabel Informasi Dunia Kerja sebesar 19,35\%, dan variabel Motivasi Memasuki Dunia Kerja sebesar 8,28\%. Jadi, total Sumbangan Efektif (SE) yaitu sebesar $72,20 \%$, sedangkan selebihnya sebesar $27,80 \%$ diberikan oleh variabel lain yang tidak diteliti dalam penelitian ini.

\section{Saran}

Berdasarkan kesimpulan yang telah diuraikan sebelumnya, peneliti dapat memberikan beberapa saran, sebagai berikut.

a. Bagi Sekolah

Dalam hal ini khususnya ditujukan kepada guru BK yang berperan aktif dalam upaya peningkatan Kesiapan Kerja siswa. Upaya peningkatan tersebut beragam, misalnya melalui penempatan praktik kerja industri yang sesuai dengan bidang keahlian siswa, pemberian Informasi Dunia Kerja secara rutin dan sesuai dengan bidang keahlian siswa, dan pemberian motivasi untuk memasuki dunia kerja kepada siswa agar siap untuk segera bekerja setelah lulus nanti.

b. Bagi Siswa

Pada variabel Pengalaman Praktik Kerja Industri terdapat skor terendah yaitu butir pernyataan nomor 8 yang berbunyi "Saya dapat menyelesaikan pekerjaan saya tepat waktu setelah melaksanakan Praktik Kerja Industri”. Hal tersebut menunjukkan tingkat kedisiplinan siswa dalam hal tepat waktu masih belum baik. Oleh karena itu, diharapkan siswa dapat bersungguhsungguh dalam melaksanakan kegiatan praktik kerja industri, sehingga kedisiplinan siswa meningkat dan mendapatkan ilmu yang baru agar dapat diterapkan setelah lulus nanti. Selanjutnya, untuk mendapatkan Informasi Dunia Kerja yang sesuai dengan bidang keahlian siswa, maka siswa harus rajin mencari informasi dari berbagai media dan tidak hanya bergantung dengan informasi yang diberikan oleh sekolah saja.

Selain itu, skor terendah pada variabel Motivasi Memasuki Dunia Kerja yaitu pada butir pernyataan nomor 1 yang berbunyi "Saya memilih bekerja daripada kuliah setelah lulus nanti". Hal tersebut menunjukkan bahwa terdapat banyak siswa yang masih belum siap untuk segera bekerja, karena ingin melanjutkan ke perguruan tinggi terlebih dahulu. Oleh karena itu, siswa diharapkan memiliki rasa percaya diri yang tinggi atas kemampuan dan keterampilan yang dimilikinya selama belajar di bangku SMK yang dapat dijadikan sebagai bekal untuk segera terjun ke dunia kerja setelah lulus nanti, karena pada dasarnya lulusan SMK dicetak untuk langsung bekerja. 
c. Bagi Penelitian selanjutnya

Penelitian ini memberikan informasi bahwa Pengalaman Praktik Kerja Industri, Informasi Dunia Kerja, dan Motivasi Memasuki Dunia Kerja secara bersama-sama berpengaruh positif terhadap Kesiapan Kerja Siswa Kelas XII Akuntansi SMK N 1 Pengasih Tahun Ajaran 2018/2019. Sumbangan Efektif (SE) yang diperoleh dalam penelitian ini yaitu sebesar 72,20\%, yang berarti bahwa Kesiapan Kerja tidak hanya dipengaruhi oleh tiga variabel yaitu Pengalaman Praktik Kerja Industri, Informasi Dunia Kerja, dan Motivasi Memasuki Dunia Kerja, namun masih terdapat $27,80 \%$ yang dipengaruhi oleh variabel lain yang tidak diteliti dalam penelitian ini. Oleh karena itu, untuk penelitian selanjutnya diharapkan mampu meneliti faktorfaktor lain yang dapat mempengaruhi Kesiapan Kerja.

\section{DAFTAR PUSTAKA}

Arikunto, S. (2013). Prosedur Penelitian: Suatu Pendekatan Praktik. Jakarta: PT Rineka Cipta.

Depdikbud. (2003). Undang-Undang RI Nomor 20, Tahun 2003, tentang Sistem Pendidikan Nasional.

Hamalik. (2007). Pengembangan Sumber Daya Manusia: Manajemen Pelatihan Ketenagakerjaan (Pendekatan Terpadu). Jakarta: Bumi Aksara.

Kardimin, A. (2004). Strategi Melamar Kerja dan Bimbingan Karier. Yogyakarta: Pustaka Pelajar.

Kemenristekdikti. (1990). Peraturan Pemerintah RI Nomor 29, Tahun 1990, tentang Pendidikan Menengah.
Kuswana, W. S. (2013). Dasar-Dasar Pendidikan Vokasi \& Kejuruan. Bandung: Alfabeta.

Mason, G., Williams, G., \& Cranmer S (2006). Employability Skills Initiatives in Higher Education: What Effects Do They on Graduate Labour Market Outcomes? Journal Education Economics, 17, 1-36.

Nugroho, B. A. (2005). Strategi Jitu Memilih Metode Statistik Penelitian dengan SPSS. Yogyakarta: Andi Offset.

Sofyan. (2015). Metodologi Pembelajaran Kejuruan. Yogyakarta: UNY Press.

Sugiyono. (2015). Metode Penelitian Kuantitatif, Kualitatif, dan $R \& D$. Bandung: Alfabeta.

(2015). Metode Penelitian Pendidikan Pendekatan Kuantitatif, Kualitatif, dan $R \& D$. Bandung: Alfabeta.

(2015). Statistika untuk Penelitian. Bandung: Alfabeta. 